\title{
Family factors, bullying victimisation and wellbeing in adolescents
}

\author{
Dieter Wolke
}

University of Warwick

D.Wolke@warwick.ac.uk

\author{
Alexandra J Skew \\ University of Essex
}

(Received May 2011 Revised November 2011)

\begin{abstract}
Bullying victimisation during adolescence has been found to be associated with a range of individual factors. In contrast, family factors have been poorly investigated or findings have been contradictory. Even less is known about factors related to victimisation in the home by siblings. A range of family factors and their relationship to bullying victimisation in school and at home was investigated in 2,163 adolescents 10-15 years old within the Understanding Society sample. Approximately $12 \%$ were victims of bullying in school overall, $4.8 \%$ of direct and $10 \%$ of relational bullying. In contrast, sibling bullying was widespread with half of all children with siblings involved in bullying each other. In particular bully/victims at home and those victimized at school were at increased risk for behaviour problems in the clinical range and were significantly less happy. Sibling bullying was found to be related to sibling composition, in particular the number of siblings and presence of brothers and to less or negative parental involvement, while school bullying was more frequent in those growing up in material deprivation at home and who were bullied by their siblings. Strengthening families and parenting skills and increasing sibling support may reduce bullying in school and increase wellbeing.
\end{abstract}

\section{Keywords}

bullying, victimisation, parenting, family, siblings, material deprivation 


\section{Introduction}

\section{Understanding Society}

Understanding Society (UKHLS) investigates whole households and includes collection of data from all adult family members and via selfcompletion questionnaires from children aged 10 to 15 years residing in the household. Thus it allows for the investigation of family factors on adolescents' wellbeing. One issue that has received much interest in recent years is bullying by peers in school and more recently, bullying by siblings at home (Wolke and Skew 2012). However, little is known how family factors affect adverse sibling relationships and how, in turn, these may be related to experience of bullying with peers at school and wellbeing. This is the overreaching question of the study reported here. However, for this analysis, only data from wave 1 of Understanding Society were available and the study outlined here is crosssectional and thus does not allow for the examination of causal pathways with respect to family factors and sibling and school bullying. Nevertheless, this unique dataset allows for the study of associations between family factors and both sibling and school bullying, and associations between sibling and school bullying and behaviour problems and unhappiness, while controlling for family factors. Once data from waves 3 and 5 of Understanding Society are available, future research will be able to determine the causal nature of these relationships and incorporate additional data sources such as school, health or criminal record data.

\section{Background}

Bullying victimisation refers to children being exposed repeatedly and over time, to negative actions on the part of one or more other peers who are or perceived to be stronger (Olweus 1993). It is systematic abuse of power with three crucial elements: repetition, intention to harm, and unequal power. Bullying can be direct including verbal abuse, hitting, kicking, beating, destroying others' belongings, or blackmail. In contrast, relational bullying refers to deliberate social exclusion of children such as ignoring, excluding them from games or parties, spreading gossip, or framing them to be humiliated (Woods and Wolke 2004). Children can be involved in bullying as either the targets of bullying (victims), as the perpetrators (bullies) or being a target but also bullying others (bully/victim). Finally, most children not involved in bullying are neutrals.

Bullying victimisation is a universal problem and the prevalence of victimisation ranges from approximately $10-25 \%$ across countries (Nansel et al 2004, Analitis et al 2009, Wolke et al 2001). Both bullying others and in particular, victimisation, is moderately stable over short to moderate periods (Sapouna et al 2011, Wolke et al 2009) and even from primary to secondary school (Schafer et al 2005). Victimisation is not random but related to individual traits and experiences, some of which may be heritable (Ball et al 2008). Children who are male, either socially withdrawn, shy or impulsive in their behaviour, have no or few friends, are disliked, show easily a reaction (e.g. cry, run away) or are emotionally dysregulated and have few coping skills, have been reported to be more likely to become victims of bullying (Stassen Berger 2007, Olweus 1994, Smith 2004, Shields and Cicchetti 2001, Veenstra 2005, Williams et al 2006). Bullying and peer victimisation is likely to originate or be maintained over time as a result of the interplay between inter- and intra-individual variables (Bronfenbrenner 1979, Swearer and Doll 2001, Dishion et al 1995) with family as a primary developmental context (Stassen Berger 2007, Smith and Myron-Wilson 1998). Parents can either directly or indirectly impact on children's peer relationships (Ladd and Kochenderfer-Ladd 1998) by being role models for use of aggressive means to achieve goals (Bandura 1973), creating internal working models of relationships in their offspring (Sroufe et al 2010) or by destabilizing intra-family relationships (Ingoldsby et al 2001). However, while family factors have been investigated in relation to perpetrators of aggression such as conduct disordered or delinquent adolescents (Fergusson et al 2004), much less is known about family factors and their relationship to peer victimisation. Where they have been investigated, findings regarding the impact of socio-economic conditions (Wolke et al 2001, Due et al 2009), parenting and bullying are inconsistent (Georgiou 2008, Veenstra 2005). Some studies have found that social deprivation, low father involvement, low parent support or low levels of family cohesion (Hart et al 2000) or harsh and reactive parenting (Barker et al 2008) and maltreatment (Shields and Cicchetti 2001) predicted victimisation. In contrast, others reported that socio-economic status is not related to 
victimisation (Wolke et al 2001) and that victims more often come from families characterised by high levels of cohesion (Bowers et al 1992), high levels of parental involvement and support (Bowers et al 1992, Baldry and Farrington 1998, Haynie et al 2001, Bowers et al 1994) and parental overprotectiveness (Berdondini and Smith 1996, Georgiou 2008, Perren and Hournung 2005). Finally, studies on family factors and bullying are mainly based on selected and small samples. In this study we take a nationally representative sample of UK adolescents, and examine how a range of family factors, including family structure, parenting behaviours and socio-economic status measures (e.g. household income and household material deprivation), are related to bullying at school.

We also consider how family factors are related to bullying amongst siblings within the home. Positive quality of sibling relationship and interaction can facilitate the acquisition of skills (Cicirelli 1995, Azmitia and Hesser 1993), the provision of emotional support (Stormshak et al 1996), protection from other family adversities such as adverse life events (Gass et al 2007), marital conflicts (Jenkins et al 2005) or poor peer relationships (Bowes et al 2010). On the other hand, physical aggression between siblings has been reported to be the most common form of family violence (Ensor et al 2010) and sibling aggression is experienced by up to half of all children in the course of a month (Wolke and Skew 2011, Duncan 1999). Unlike friendships but similar to peer relationships in the classroom, sibling relationships are involuntary, i.e. children cannot choose the siblings they live with, but are born into these relationships. Siblings are rarely equal in terms of age, size and physical or psychological strength; therefore there is an imbalance of power. Furthermore, the direct or indirect attacks are not single events but are frequent and repeated. Finally, similar to peers confined in the same group, siblings spend considerable amounts of time together, often in the absence of an adult, which provides significant opportunities for the bullying of one sibling by another. Time spent together leads to familiarity that can breed contempt. This means they know exactly how to provoke or upset their siblings (Ensor et al 2010). Sibling interactions are emotionally charged relationships defined by strong, uninhibited emotions of positive, negative and sometimes ambivalent quality (Brody 2004).
Yet, compared to bullying at school, much less research has considered repeated intention to harm, i.e. bullying between siblings, and no previous study has considered how family factors such as parenting behaviours might be related to sibling bullying. Experience of sibling bullying, in particular as victims who also bully (bully/victim) has also been reported to increase the likelihood of being a victim of bullying at school (Menesini et al 2010, Duncan 1999, Wolke and Samara 2004). We examine this association in this study, whilst controlling for family factors.

But does bullying at home or at school matter for wellbeing? Bully/victims and those involved in both relational and direct aggression have been found to most likely exhibit externalising problems (Wolke et al 2000), anxiety and depression (Hawker and Boulton 2000) or psychotic symptoms (Bebbington et al 2004), with increasing evidence for a dose-response relationship (Wolke and Skew 2011). Longitudinal studies support these findings, with victims of bullying in primary school more often suffering internalising and externalising problems (Kumpulainen et al 2001), and more likely to have psychiatric diagnoses years later (Sourander et al 2007, Sugden et al 2010). Furthermore, a doseresponse relationship was reported between multiple victimisation by adults and peers and psychosis-like symptoms (Schreier et al 2009, Arseneault et al 2011). Conversely, positive family and sibling relationships and neighbourhood support can protect children from the adverse impact of victimisation (Bowes et al 2009). Thus, are sibling and school bullying related to behaviour problems and unhappiness? Furthermore, are these relationships maintained once we control for family factors? An understanding of family factors, their relationship to bullying at home and school and adolescent wellbeing, should not only aid future longitudinal research, but provide first indications for potential family-based interventions to prevent bullying in school.

\section{Methods \\ Study}

Data were derived from the Youth Questionnaire, as well as the adult interview and adult self-completion questionnaire, collected as part of Understanding Society, the UK household longitudinal study, a new household survey which 
began in 2009 and interviews 40,000 households across the United Kingdom

(www.understandingsociety.org.uk/)

Fieldwork for each wave of Understanding Society is spread over a 2 year period.

\section{Sample}

The sample is taken from the first year of the first wave, which interviewed around 14,000 households, amounting to 22,265 adult interviews and 2,163 self-completed questionnaires by youths aged 10-15. Characteristics of the youth sample, as well as characteristics of the parents of the youth sample, can be found in Tables 1 and 2 respectively, of the Early Findings report (Wolke and Skew 2011). Questions relating to bullying at school were asked of all youths completing the Youth Questionnaire. In addition, questions relating to bullying with siblings at home were asked of all those that reported having siblings at home. We restrict our analysis to include only children that had at least one sibling in the household and for which information on both sibling and school bullying was available $(\mathrm{N}=1,823)$, given our interest in exploring the relationship between sibling and school bullying. Dealing with item non-response on the explanatory variables of interest yielded a final sample size of 1,746 youths ${ }^{i}$.

\section{Bullying Measures}

Children (with siblings) were identified as being involved in sibling bullying, using several questions relating to bullying perpetration and victimisation over the last six months. These questions have been used previously and are well validated (Wolke and Samara 2004, Menesini et al 2010, Wolke and Skew, 2012). Firstly children were asked "How often do any of your brothers or sisters do any of the following to you at home?" with the options "hit, kick, or push you", "take your belongings", "call you nasty names" and "make fun of you". Response categories then determine the frequency of each option: never; not much; quite a lot (more than 4 times in the last 6 months); a lot (a few times every week). Following this question children were asked whether they were the perpetrator of bullying towards their siblings "How often do you do any of the following to your brothers or sisters at home?" with the same options and response categories as mentioned above. Children who reported experiencing or perpetrating one or more of these behaviours 'quite a lot' or 'a lot' were considered as being involved in sibling bullying. Four groups were constructed: 'neutral', 'pure victim', 'bully/victim' and 'pure bully'.

\section{School bullying}

School bullying was determined by an adapted version of the Child Relationship Questionnaire (Wolke et al 2000, Hamburger et al 2011, p.60-63). The following question "How often do you get physically bullied at school, for example getting pushed around, hit or threatened or having belongings stolen?" and then "How often do you get bullied in other ways at school such as getting called nasty names, getting left out of games, or having nasty stories spread about you on purpose?". As with the sibling bullying questions, children were also asked whether or not they were the perpetrators of such bullying. Again, children experiencing or perpetrating one or more of these types of bullying 'quite a lot' (more than 4 times in the last 6 months) or 'a lot' (a few times every week) were considered victims or bullying perpetrators. Although we intended to construct the same groups of victim, bully/victim and bully vs. neutrals, this was not possible, as less than $1 \%$ (22 adolescents) reported frequent bullying. Thus we constructed one overall variable of any victim of bullying at school (see Figure 1).

\section{Behaviour Problems}

These were determined with the Strength and Difficulties Questionnaire (SDQ) (Goodman 2001) and clinically relevant total problems constructed as a total score above the $90^{\text {th }}$ percentile determined within this sample.

\section{Unhappiness}

Youths were asked a number of questions relating to how they felt about different aspects of their life including family, friends and their life as a whole. An overall happiness scale was created by reverse coding and then combining the scores for each item (alpha 0.73) (Chan and Koo 2010). Unhappy youths were those with scores less than the $10^{\text {th }}$ percentile of all Understanding Society adolescents (see Wolke and Skew 2011).

\section{Family Factors}

The family factors were obtained from the interviews with the adult household members and consisted of the type of family in which the youth 
lived (i.e. whether the youth lived with two natural parents, a lone-parent or step-parent family), the type and number of siblings in the household, the ordinal position of the child compared with his/her siblings (i.e. eldest, youngest, middle/twin), the composition of siblings (brothers, sisters, mixture), parenting behaviour (mother's response to questions such as "Most children have quarrels with their parents at some time. How often do you quarrel with your child/any of your children?"; "How often do you praise your child/any of your children?"; "How often do you cuddle or hug your child/any of your children?"), household income and deprivation (see Knies 2011), parental education and finally maternal mental health, measured using the General Health Questionnaire (GHQ), which is a commonly used screening instrument for psychiatric morbidity (Bowling 2005). For the maternal GHQ scores, a threshold of four was used to determine mothers with a mental health problem (Goldberg et al 1998). Other characteristics we considered are child age, gender and UK country.

\section{Statistical Analysis.}

Bivariate analyses (Chi-Square, ANOVA) were used to examine the relationship between each family or individual factor and sibling bullying or school bullying (Table 1). Following this, multivariate analysis using multinomial and binary logistic regression models was applied to investigate the independent association between family/individual factors and sibling bullying (Table 2 , model 1 ) and school bullying (Table 2, model 2 ). In model 3 (Table 2), in addition to family and individual factors, sibling bullying was also included as an explanatory factor. Finally, the relationship between bullying at home and/or at school and behaviour problems and happiness was investigated, using multiple logistic regression after controlling for both family and individual factors.

\section{Results}

\section{Prevalence of sibling and school bullying}

Over half of all children with siblings (54\%) were involved in some type of bullying at home. Most common was to be both a bully and a victim (bully/victim: 34\%), with the rest pure victims (16\%) and a small proportion of pure bullies (4\%) (Figure 1). At school, $12 \%$ of children reported being a victim of physical or relational bullying (Figure 1).

\section{Figure 1. Prevalence of sibling bullying involvement and of victimisation at school by peers}

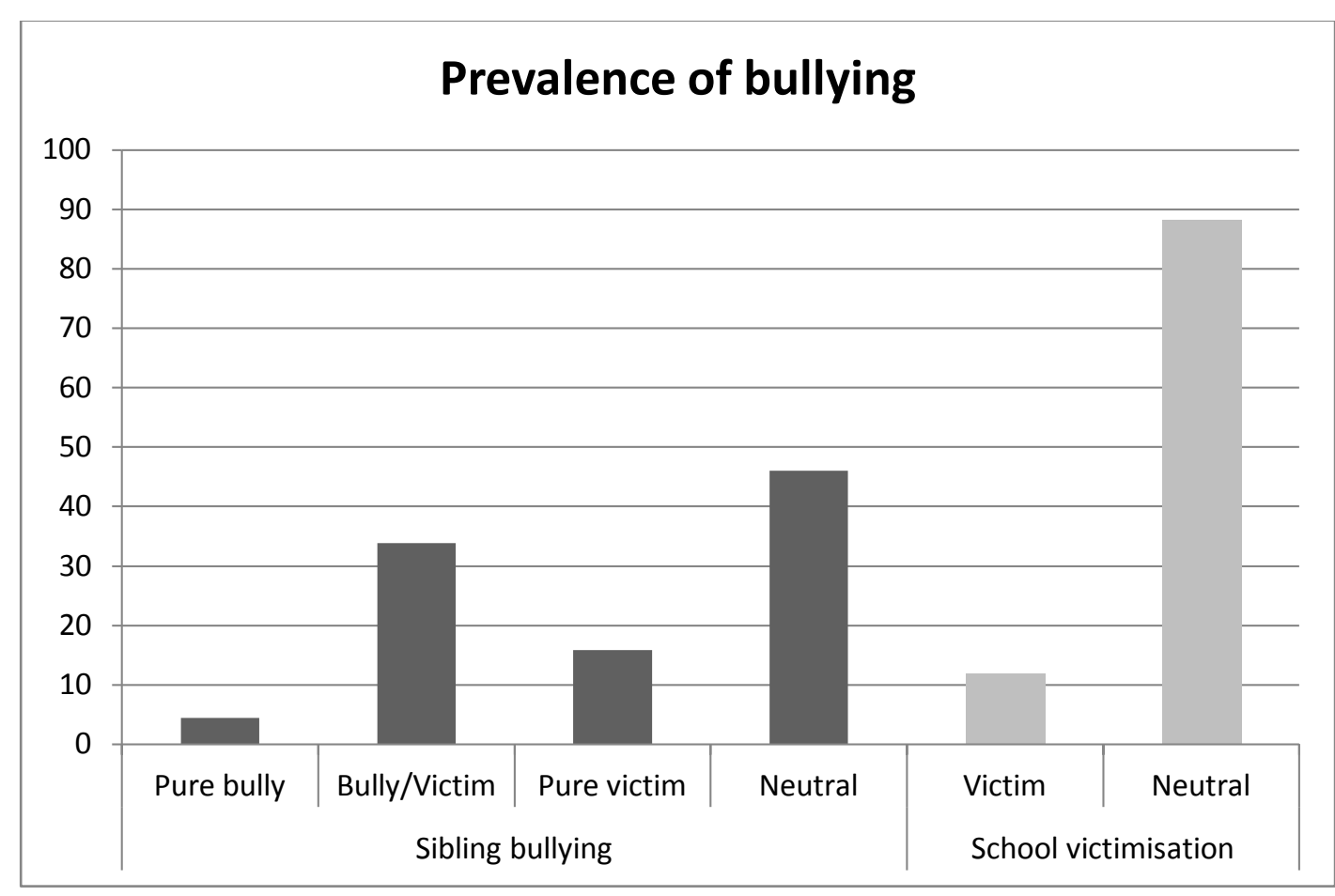




\section{Bivariate analysis of family and individual factors and sibling and school bullying}

Table 1 shows the relationship between individual, socioeconomic, and family factors and bullying among siblings and at school.

\section{Sibling bullying}

No country differences in the prevalence of different types of bullying at home were found. However, males were more likely to be bullies or bully/victims, and girls more likely to be pure victims. We also found younger children (aged 1012) were more often pure victims, whereas older children (aged 13-15) were more often pure bullies or bully/victims (Table 1).
Family or sibling types were not associated with sibling bullying, but number of siblings and composition of siblings were important. Having more than one sibling, and in particular, having brothers or a mixture of brothers and sisters, increased the chance of being involved in some sort of sibling bullying. Ordinal position was also associated with sibling bullying, with youngest children being the least likely to be involved in any kind of bullying behaviour. Household income, material deprivation and parental education levels were not associated with sibling bullying, however, youths living in a family in income poverty (household income less than $60 \%$ median income) were more likely to be involved in sibling bullying, particularly as bully/victims. 
Table 1. Association of sibling bullying, bullying at school and both sibling and school bullying with family and individual factors, percentages

\begin{tabular}{|c|c|c|c|c|c|c|c|}
\hline \multirow[b]{2}{*}{ Explanatory variable } & \multicolumn{4}{|c|}{ Sibling bullying } & \multicolumn{2}{|c|}{ School bullying } & \multirow[b]{2}{*}{$\mathbf{N}$} \\
\hline & $\begin{array}{l}\text { Pure } \\
\text { bully }\end{array}$ & $\begin{array}{l}\text { Bully/ } \\
\text { Victim }\end{array}$ & $\begin{array}{c}\text { Pure } \\
\text { victim }\end{array}$ & Neutral & Victim & Neutral & \\
\hline \multicolumn{8}{|l|}{ Country } \\
\hline England & 4.5 & 35.0 & 15.6 & 44.9 & 12.1 & 87.9 & 1349 \\
\hline Wales/Scotland/N.I. & 4.8 & 32.5 & 15.6 & 47.1 & 9.8 & 90.2 & 397 \\
\hline \multicolumn{8}{|l|}{ Sex } \\
\hline Male & 5.8 & 35.9 & 14.8 & 43.6 & 12.4 & 87.6 & 881 \\
\hline Female & 3.2 & 33.0 & 16.5 & 47.3 & 10.8 & 89.3 & 865 \\
\hline \multicolumn{8}{|l|}{ Age } \\
\hline $10-12$ years & 3.5 & 33.8 & 18.2 & 44.6 & 14.0 & 86.0 & 870 \\
\hline $13-15$ years & 5.6 & 35.1 & 13.1 & 46.2 & 9.1 & 90.9 & 876 \\
\hline \multicolumn{8}{|l|}{ Family type } \\
\hline 2 natural parents & 4.7 & 32.6 & 15.5 & 47.2 & 10.3 & 89.7 & 1083 \\
\hline Other & 4.2 & 37.4 & 15.8 & 42.5 & 13.6 & 86.4 & 663 \\
\hline \multicolumn{8}{|l|}{ Sibling type } \\
\hline Natural siblings & 4.8 & 34.3 & 15.4 & 45.5 & 11.0 & 89.0 & 1505 \\
\hline Half siblings & 2.9 & 39.1 & 17.8 & 40.2 & 17.2 & 82.8 & 174 \\
\hline Step/other siblings & 3.0 & 25.4 & 14.9 & 56.7 & 10.5 & 89.6 & 67 \\
\hline \multicolumn{8}{|l|}{ Number of siblings } \\
\hline 1 sibling & 4.2 & 30.5 & 15.2 & 50.2 & 11.4 & 88.6 & 889 \\
\hline 2 siblings & 5.9 & 37.3 & 15.9 & 40.9 & 10.6 & 89.4 & 577 \\
\hline 3 or more siblings & 2.9 & 41.1 & 16.4 & 39.6 & 14.3 & 85.7 & 280 \\
\hline \multicolumn{8}{|l|}{ Ordinal position } \\
\hline Eldest & 4.0 & 35.3 & 17.1 & 43.6 & 12.6 & 87.4 & 683 \\
\hline Youngest & 4.7 & 31.0 & 13.8 & 50.6 & 11.0 & 89.0 & 617 \\
\hline Middle/twin & 5.2 & 37.9 & 15.9 & 41.0 & 10.8 & 89.2 & 446 \\
\hline \multicolumn{8}{|l|}{ Sibling composition } \\
\hline Brothers & 5.3 & 35.3 & 16.8 & 42.7 & 10.9 & 89.1 & 644 \\
\hline Sisters & 3.7 & 30.4 & 14.9 & 51.0 & 12.5 & 87.5 & 625 \\
\hline Mixture & 4.6 & 38.6 & 15.1 & 41.7 & 11.3 & 88.7 & 477 \\
\hline \multicolumn{8}{|l|}{ Income poverty } \\
\hline Not poor & 4.5 & 32.4 & 15.9 & 47.1 & 10.9 & 89.1 & 1280 \\
\hline Poor & 4.5 & 39.9 & 14.8 & 40.8 & 13.3 & 86.7 & 466 \\
\hline \multicolumn{8}{|l|}{ Income quintile } \\
\hline $1^{\text {st }}$ & 4.5 & 39.9 & 14.8 & 40.8 & 13.3 & 86.7 & 466 \\
\hline $2^{\text {nd }}$ & 5.3 & 31.7 & 16.3 & 46.7 & 10.4 & 89.6 & 375 \\
\hline $3^{\text {rd }}$ & 4.9 & 32.0 & 16.4 & 46.8 & 13.0 & 87.0 & 391 \\
\hline $4^{\text {th }}$ & 3.1 & 32.7 & 18.2 & 46.1 & 9.3 & 90.7 & 291 \\
\hline $5^{\text {th }}$ & 4.5 & 34.1 & 11.7 & 49.8 & 10.3 & 89.7 & 223 \\
\hline \multicolumn{8}{|l|}{ Parent's education } \\
\hline Degree & 6.1 & 34.6 & 16.0 & 43.3 & 10.2 & 89.8 & 462 \\
\hline Other higher qual & 2.6 & 36.7 & 16.0 & 44.7 & 10.9 & 89.1 & 275 \\
\hline A levels & 2.9 & 34.1 & 16.6 & 46.4 & 12.2 & 87.8 & 343 \\
\hline GCSE or lower & 5.1 & 33.5 & 14.7 & 46.7 & 12.5 & 87.5 & 666 \\
\hline $\begin{array}{l}\text { Household material } \\
\text { deprivation (mean) }\end{array}$ & 0.18 & 0.17 & 0.16 & 0.15 & 0.20 & 0.15 & 1746 \\
\hline
\end{tabular}


(Table 1 cont'd)

\begin{tabular}{|c|c|c|c|c|c|c|c|}
\hline \multirow[b]{2}{*}{ Explanatory variable } & \multicolumn{4}{|c|}{ Sibling bullying } & \multicolumn{2}{|c|}{ School bullying } & \multirow[b]{2}{*}{$\mathbf{N}$} \\
\hline & $\begin{array}{l}\text { Pure } \\
\text { bully }\end{array}$ & $\begin{array}{l}\text { Bully/ } \\
\text { Victim }\end{array}$ & $\begin{array}{l}\text { Pure } \\
\text { victim }\end{array}$ & Neutral & Victim & Neutral & \\
\hline \multicolumn{8}{|l|}{$\begin{array}{l}\text { How often eat dinner with } \\
\text { child/ren }\end{array}$} \\
\hline Less than 2 times & 2.5 & 37.7 & 18.1 & 41.7 & 14.6 & 85.4 & 199 \\
\hline 3-5 times & 3.8 & 37.8 & 14.8 & 43.7 & 8.6 & 91.5 & 339 \\
\hline 6-7 times & 5.1 & 33.0 & 15.5 & 46.5 & 11.9 & 88.1 & 1208 \\
\hline \multicolumn{8}{|l|}{$\begin{array}{l}\text { Freq. leisure time with } \\
\text { child/ren }\end{array}$} \\
\hline Once a month or less & 5.1 & 39.4 & 15.8 & 39.6 & 13.1 & 86.9 & 487 \\
\hline Several times a month & 5.0 & 32.2 & 15.5 & 47.4 & 9.7 & 90.3 & 382 \\
\hline About once a week & 5.1 & 34.8 & 14.7 & 45.4 & 12.2 & 87.8 & 491 \\
\hline Several times a week & 2.6 & 29.8 & 16.8 & 50.8 & 10.6 & 89.4 & 386 \\
\hline \multicolumn{8}{|l|}{$\begin{array}{l}\text { How often quarrel with } \\
\text { child/ren }\end{array}$} \\
\hline $\begin{array}{l}\text { Most days/more than once a } \\
\text { week }\end{array}$ & 4.7 & 40.4 & 16.0 & 38.9 & 12.2 & 87.8 & 929 \\
\hline $\begin{array}{l}\text { Less than once a week/hardly } \\
\text { ever }\end{array}$ & 4.3 & 27.7 & 15.2 & 52.9 & 10.9 & 89.1 & 817 \\
\hline \multicolumn{8}{|l|}{$\begin{array}{l}\text { How often talk about } \\
\text { important matters with child }\end{array}$} \\
\hline Most days & 4.5 & 34.0 & 16.4 & 45.0 & 12.1 & 87.9 & 1102 \\
\hline More than once a week & 4.9 & 32.2 & 13.6 & 49.3 & 11.6 & 88.4 & 450 \\
\hline Less than once a week & 3.6 & 41.8 & 16.0 & 38.7 & 8.8 & 91.2 & 194 \\
\hline \multicolumn{8}{|l|}{$\begin{array}{l}\text { How often involve child in } \\
\text { setting the rules }\end{array}$} \\
\hline Never/seldom & 3.8 & 35.0 & 15.2 & 46.1 & 11.6 & 88.4 & 614 \\
\hline Sometimes & 4.9 & 34.7 & 15.6 & 44.9 & 11.6 & 88.4 & 912 \\
\hline Very often & 5.0 & 31.8 & 17.3 & 45.9 & 11.4 & 88.6 & 220 \\
\hline \multicolumn{8}{|l|}{ How often praise child } \\
\hline Never/seldom/sometimes & 6.9 & 35.2 & 15.0 & 43.0 & 11.5 & 88.5 & 321 \\
\hline Very often & 4.0 & 34.3 & 15.8 & 46.0 & 11.6 & 88.4 & 1425 \\
\hline \multicolumn{8}{|l|}{ How often slap child } \\
\hline Never & 5.0 & 32.0 & 15.3 & 47.7 & 11.2 & 88.8 & 1324 \\
\hline Seldom/sometimes/often & 3.1 & 41.9 & 16.8 & 38.2 & 12.8 & 87.2 & 422 \\
\hline \multicolumn{8}{|l|}{ How often cuddle child } \\
\hline Never/seldom/sometimes & 5.5 & 36.8 & 14.2 & 43.6 & 8.7 & 91.3 & 310 \\
\hline Very often & 4.3 & 33.9 & 16.0 & 45.8 & 12.2 & 87.8 & 1436 \\
\hline \multicolumn{8}{|l|}{ How often shout at child } \\
\hline Never/seldom & 6.4 & 25.1 & 15.4 & 53.1 & 8.4 & 91.6 & 358 \\
\hline Sometimes/very often & 4.0 & 36.8 & 15.7 & 43.4 & 12.4 & 87.6 & 1388 \\
\hline \multicolumn{8}{|l|}{$\begin{array}{l}\text { Parent has mental health } \\
\text { problem }\end{array}$} \\
\hline No & 4.0 & 33.7 & 15.4 & 46.8 & 10.9 & 89.1 & 1290 \\
\hline Yes & 5.0 & 36.9 & 17.1 & 41.1 & 14.9 & 85.1 & 363 \\
\hline Missing & 9.7 & 34.4 & 12.9 & 43.0 & 7.5 & 92.6 & 93 \\
\hline$p<.05$ & & & & & & & \\
\hline
\end{tabular}


Parenting behaviour including the frequency of leisure time spent with children, and how often the child's mother quarrelled with, slapped or shouted at her child/children were all significantly associated with sibling bullying. Increasing amounts of leisure time with children was associated with decreasing involvement in bullying at home. Increased occasions of quarrelling, slapping or shouting at children were associated with increased involvement in bullying behaviours, particularly as bully/victims. In contrast, parental mental health showed no association with bullying at home.

\section{School bullying}

Few individual and family factors were associated with victimisation at school. As was found with sibling bullying, older children (aged 13-15) were less likely to be a victim of bullying at school (9.1\%) than younger children (14.0\%). However, no gender differences in victimisation were found. Living in a step, lone parent or other type of family was associated with higher levels of victimisation, and children with half siblings were also more likely to be involved in bullying at school. Though number of siblings, ordinal position and sibling composition were important in relation to sibling bullying, they had no relationship with bullying at school. Household income, parental education and whether or not the family was in income poverty were also not associated with bullying at school. However, victims of bullying were more likely to come from families with higher levels of material deprivation compared to neutral children (Table 1). In terms of the measures of parenting behaviour, except for shouting at children which was associated with higher levels of victimisation (and weakly, frequency of eating dinner with, or cuddling children), none of the other parenting measures were significantly associated with peer victimisation. Lastly, children whose mother had a mental health problem, were more likely to be victimised at school compared with children whose mothers did not, or for which their mental health could not be determined due to missing data (though this was only significant at the $10 \%$ level).
Multivariate analysis of family and individual factors and sibling and school bullying

To determine the relationship of each of the family and individual factors with sibling and school bullying in the presence of the other variables, we carried out multinomial and binary logistic regression models, the results of which can be seen in Table 2. Included in these models are all the factors that were significantly associated (at the $5 \%$ level) with either sibling or school bullying in the bivariate analyses.

Sibling bullying and its association with individual, socioeconomic, and family factors

Model 1 of Table 2 shows the relationship between the family and individual factors and sibling bullying, using multinomial logistic regression. Associations are shown in terms of odds ratios. Similar to the bivariate analysis, both sex and age were significantly associated with sibling bullying; girls were significantly less likely to be pure bullies, and older children were less likely to become the victim of sibling bullying. We find a weak indication that those living in step or lone parent families were more likely to be bully/victims, compared with those living with two natural parents. Conversely, living with step or other types of siblings (i.e. foster or a combination of different types of siblings) compared with living with only natural siblings, was associated with lower odds of being a bully/victim. Number of siblings was also associated with being a bully/victim: children with only one sibling had a lower chance of being a bully/victim relative to being neutral. Being a youngest child, relative to being the eldest, was associated with a lower chance of becoming a pure victim, however ordinal position had no association with other types of sibling bullying. Sibling composition was important for all types of sibling bullying, with youths with brothers the most likely to be involved in some sort of bullying. After controlling for family and individual factors, neither income poverty, nor household material deprivation, were significantly associated with sibling bullying. 
Table 2. Multinominal and logistic regression models (odds ratios) predicting bullying at home and at school, controlling for individual and family factors (Model 1 and 2) and additionally sibling bullying (Model 3)

\begin{tabular}{|c|c|c|c|c|c|}
\hline \multirow[b]{2}{*}{ Explanatory variable } & \multicolumn{3}{|c|}{$\begin{array}{l}\text { Model 1: Sibling bullying and } \\
\text { individual and family factors }\end{array}$} & \multirow{2}{*}{$\begin{array}{c}\text { Model 2: School } \\
\text { bullying and } \\
\text { individual and } \\
\text { family factors }\end{array}$} & \multirow{2}{*}{$\begin{array}{c}\text { Model 3: School } \\
\text { bullying, individual } \\
\text { factors and sibling } \\
\text { bullying }\end{array}$} \\
\hline & $\begin{array}{l}\text { Pure } \\
\text { bully }\end{array}$ & $\begin{array}{l}\text { Bully/ } \\
\text { Victim }\end{array}$ & $\begin{array}{l}\text { Pure } \\
\text { victim }\end{array}$ & & \\
\hline \multicolumn{6}{|l|}{ Sex } \\
\hline Male (r) & - & - & - & - & - \\
\hline Female & $0.54^{*}$ & 0.88 & 1.09 & 0.86 & 0.88 \\
\hline \multicolumn{6}{|l|}{ Age } \\
\hline $10-12$ years $(r)$ & - & - & - & - & - \\
\hline $13-15$ years & 1.51 & 1.04 & $0.68^{* *}$ & $0.62^{* *}$ & $0.62^{* *}$ \\
\hline \multicolumn{6}{|l|}{ Family type } \\
\hline 2 natural parents $(r)$ & - & - & - & - & - \\
\hline Other & 1.08 & $1.24^{+}$ & 1.12 & 1.15 & 1.12 \\
\hline \multicolumn{6}{|l|}{ Sibling type } \\
\hline Natural siblings (r) & - & - & - & - & - \\
\hline Half siblings & 0.62 & 1.02 & 1.11 & 1.40 & 1.39 \\
\hline Step/other siblings & 0.55 & $0.49^{*}$ & 0.68 & 0.89 & 1.00 \\
\hline \multicolumn{6}{|l|}{ Number of siblings } \\
\hline 1 sibling $(r)$ & - & - & - & - & - \\
\hline 2 siblings & 1.63 & $1.43^{*}$ & 1.35 & 1.09 & 1.03 \\
\hline 3 or more siblings & 0.81 & $1.67^{*}$ & 1.59 & $1.70^{\dagger}$ & 1.60 \\
\hline \multicolumn{6}{|l|}{ Ordinal position } \\
\hline Eldest $(r)$ & - & - & - & - & - \\
\hline Youngest & 1.03 & 0.88 & $0.70^{*}$ & 0.88 & 0.89 \\
\hline Middle/twin & 1.26 & 0.90 & 0.84 & 0.70 & 0.71 \\
\hline \multicolumn{6}{|l|}{ Sibling composition } \\
\hline Brothers $(r)$ & - & - & - & - & - \\
\hline Sisters & $0.61^{\dagger}$ & $0.72^{*}$ & $0.75^{+}$ & 1.17 & 1.24 \\
\hline Mixture & 0.71 & 0.80 & 0.70 & 0.81 & 0.84 \\
\hline \multicolumn{6}{|l|}{ Income poverty } \\
\hline Not poor $(r)$ & - & - & - & - & - \\
\hline Poor & 1.02 & 1.18 & 0.93 & 0.97 & 0.94 \\
\hline $\begin{array}{l}\text { Household material } \\
\text { deprivation }\end{array}$ & 1.92 & 0.63 & 0.79 & $2.48^{*}$ & $2.58^{*}$ \\
\hline \multicolumn{6}{|l|}{$\begin{array}{l}\text { Freq. leisure time with } \\
\text { child/ren }\end{array}$} \\
\hline Once a month or less $(r)$ & - & - & - & - & - \\
\hline Several times a month & 0.87 & $0.69^{*}$ & 0.78 & 0.74 & 0.78 \\
\hline About once a week & 0.93 & $0.76^{\dagger}$ & 0.75 & 0.98 & 1.01 \\
\hline Several times a week & $0.42^{*}$ & $0.59^{* *}$ & 0.74 & 0.81 & 0.88 \\
\hline
\end{tabular}


(Table 2 cont'd)

\section{Model 1: Sibling bullying and individual and family factors}

\author{
Model 2: School \\ bullying and \\ individual and \\ family factors
}

\author{
Model 3: School \\ bullying, individual \\ factors and sibling \\ bullying
}

\begin{tabular}{|c|c|c|c|c|c|}
\hline Explanatory variable & $\begin{array}{l}\text { Pure } \\
\text { bully }\end{array}$ & $\begin{array}{l}\text { Bully/ } \\
\text { Victim }\end{array}$ & $\begin{array}{c}\text { Pure } \\
\text { victim }\end{array}$ & Victim & Victim \\
\hline \multicolumn{6}{|l|}{$\begin{array}{l}\text { How often quarrel with } \\
\text { child/ren }\end{array}$} \\
\hline $\begin{array}{l}\text { Most days/more than once } \\
\text { a week }\end{array}$ & $1.73^{*}$ & $1.69^{* *}$ & $1.32^{\dagger}$ & 0.96 & 0.87 \\
\hline $\begin{array}{l}\text { Less than once a } \\
\text { week/hardly ever }(r)\end{array}$ & - & - & - & - & - \\
\hline \multicolumn{6}{|l|}{ How often slap child } \\
\hline Never $(r)$ & - & - & - & - & - \\
\hline Seldom/sometimes/often & 0.76 & $1.30^{\dagger}$ & 1.13 & 0.97 & 0.94 \\
\hline \multicolumn{6}{|l|}{ How often shout at child } \\
\hline Never/seldom (r) & - & - & - & - & - \\
\hline Sometimes/very often & 0.62 & $1.30^{\dagger}$ & 0.97 & 1.41 & 1.38 \\
\hline \multicolumn{6}{|l|}{ Sibling bullying } \\
\hline Pure bully & & & & & 1.68 \\
\hline Bully/Victim & & & & & $2.23^{* *}$ \\
\hline Pure victim & & & & & $1.61^{*}$ \\
\hline$N_{* *}$ Neutral $(r)$ & & & & & - \\
\hline
\end{tabular}

Of the parenting behaviours, engaging in leisure time several times a week compared with only once a month reduced the odds of becoming a pure bully or a bully/victim. Frequent quarrelling with children increased the odds of children becoming involved in all kinds of bullying, but particularly as a pure bully or a bully/victim. Moreover, there is some suggestion from the model, that slapping $(p=0.051)$ or shouting at the child $(p=0.088)$ increased the likelihood of the child being a bully/victim.

School victimisation and its association with individual, socio-economic, and family factors

Model 2, Table 2 shows the odds ratios estimated from a logistic regression model predicting the probability of being a victim of bullying at school, controlling for a range of individual and family factors. The results indicate no gender differences in relation to school bullying, however, older children were less likely to be victims of bullying than younger children. As expected from the bivariate analysis, few family factors were related to bullying at school. Having three or more siblings was associated with increased odds of being a victim of bullying at school, but this was only a trend $(p<.10)$. By contrast, increasing levels of household material deprivation were significantly associated with a higher chance of being a victim of bullying at school (Table 2).

The relationship between sibling and school bullying, controlling for individual, socio-economic, and family factors

Model 3, Table 2, further examines the association between bullying at home and bullying at school, controlling for the individual, socioeconomic and family factors which were demonstrated to be associated with sibling bullying in Model 1. Model 3 shows that even after controlling for a number of family factors, sibling bullying still has a strong association with victimisation at school. Bully/victims have over twice the odds of being victims of bullying at school $(p<0.001)$. Moreover, we found that pure victims at home have one and a half times the odds of being a victim of bullying at school $(p<0.05)$ while bullying 
perpetration was not related to victimisation at school.

Bullying involvement, behaviour problems and unhappiness

Previous analysis of bullying among youths in Understanding Society (Wolke and Skew 2011) indicated a strong association between bullying at home and bullying at school, and both abnormal SDQ scores and unhappiness. Taking this one step further here, it was asked whether these relationships are maintained once controlled for individual, socio-economic and family factors. Table 3 shows the results of two logistic regression models predicting firstly, the relationship between bullying within the home, and at school, and abnormal SDQ scores (Model 1, Table 3) and secondly, bullying within the home, and at school, and youth unhappiness (Model 2, Table 3), controlling for individual, socio-economic and family factors. The results indicate that controlling for family and socio-economic factors previously found to be associated with both sibling and school bullying (Table 2), did not alter the association between sibling bullying or peer bullying, and both abnormal SDQ or unhappiness. Sibling bully/victims were three times more likely to have SDQ scores in the abnormal range, and pure sibling bullies had twice the odds of abnormal SDQ scores (though this was only marginally significant $p=0.052$ ). Victims of bullying at school, have over five times the odds of abnormal SDQ scores. Similarly, the odds of being unhappy were increased five times for victims of bullying at school, and were around twice as high for children that engaged in any type of bullying within the home (victims, bully/victims, pure bully). Both sibling and school bullying experiences made an independent contribution to predicting behaviour problems and unhappiness.

Table 3: Logistic regression models predicting behaviour problems and unhappiness, controlling for individual and family factors

\begin{tabular}{|c|c|c|}
\hline Explanatory variable & $\begin{array}{c}\text { Model 1: Behaviour problems } \\
\text { Odds ratios }\end{array}$ & $\begin{array}{c}\text { Model 2: Unhappiness } \\
\text { Odds ratios }\end{array}$ \\
\hline \multicolumn{3}{|l|}{ Sex } \\
\hline Male (r) & - & - \\
\hline Female & 0.95 & 1.20 \\
\hline \multicolumn{3}{|l|}{ Age } \\
\hline $10-12$ years $(r)$ & - & - \\
\hline 13-15 years & 0.79 & $1.93^{* *}$ \\
\hline \multicolumn{3}{|l|}{ Family type } \\
\hline 2 natural parents $(r)$ & - & - \\
\hline Other & $0.69^{\dagger}$ & 1.05 \\
\hline \multicolumn{3}{|l|}{ Sibling type } \\
\hline Natural siblings ( $r$ ) & - & - \\
\hline Half siblings & $2.70^{* *}$ & 1.20 \\
\hline Step/other siblings & $3.79^{* *}$ & $2.22^{*}$ \\
\hline \multicolumn{3}{|l|}{ Number of siblings } \\
\hline 1 sibling $(r)$ & - & - \\
\hline 2 siblings & 1.14 & 0.97 \\
\hline 3 or more siblings & 0.75 & 1.18 \\
\hline \multicolumn{3}{|l|}{ Ordinal position } \\
\hline Eldest $(r)$ & - & - \\
\hline Youngest & 1.06 & 1.22 \\
\hline Middle/twin & 0.94 & 1.30 \\
\hline
\end{tabular}


(Table 3 cont'd)

\begin{tabular}{|c|c|c|}
\hline Explanatory variable & $\begin{array}{c}\text { Model 1: Behaviour problems } \\
\text { Odds ratios }\end{array}$ & $\begin{array}{c}\text { Model 2: Unhappiness } \\
\text { Odds ratios }\end{array}$ \\
\hline \multicolumn{3}{|l|}{ Sibling composition } \\
\hline Brothers $(r)$ & - & - \\
\hline Sisters & $1.50^{\dagger}$ & $1.43^{\dagger}$ \\
\hline Mixture & 1.43 & 0.99 \\
\hline \multicolumn{3}{|l|}{ Income poverty } \\
\hline Not poor $(r)$ & - & - \\
\hline Poor & 1.11 & 0.71 \\
\hline $\begin{array}{l}\text { Household material } \\
\text { deprivation }\end{array}$ & $3.67^{*}$ & $4.61^{* *}$ \\
\hline \multicolumn{3}{|l|}{ Freq. leisure time with } \\
\hline Once a month or less ( $r$ ) & - & - \\
\hline Several times a month & $0.54^{*}$ & 0.86 \\
\hline About once a week & 0.69 & $0.62^{*}$ \\
\hline Several times a week & $0.52^{*}$ & $0.53^{*}$ \\
\hline \multicolumn{3}{|l|}{$\begin{array}{l}\text { How often quarrel with } \\
\text { child/ren }\end{array}$} \\
\hline $\begin{array}{l}\text { Most days/more than } \\
\text { once a week }\end{array}$ & $1.47^{+}$ & $1.46^{*}$ \\
\hline $\begin{array}{l}\text { Less than once a } \\
\text { week/hardly ever ( } r \text { ) }\end{array}$ & - & - \\
\hline \multicolumn{3}{|l|}{ How often slap child } \\
\hline Never $(r)$ & - & - \\
\hline Seldom/sometimes/often & 1.15 & 1.10 \\
\hline \multicolumn{3}{|l|}{ How often shout at child } \\
\hline Never/seldom (r) & - & - \\
\hline Sometimes/very often & 0.93 & $0.65^{\dagger}$ \\
\hline \multicolumn{3}{|l|}{ Sibling bullying } \\
\hline Pure bully & $2.38^{\dagger}$ & $2.59^{* *}$ \\
\hline Bully/Victim & $2.91^{* *}$ & $2.25^{* *}$ \\
\hline Pure victim & 1.58 & $1.97^{* *}$ \\
\hline Neutral $(r)$ & - & - \\
\hline \multicolumn{3}{|l|}{ School bullying } \\
\hline Neutral & - & - \\
\hline Victim & $5.31^{* *}$ & $5.10^{* *}$ \\
\hline$p<.01^{*} p<.05^{\dagger} p<0.1$ & & \\
\hline
\end{tabular}

\section{Discussion}

This is the first report of sibling and peer bullying in a representative sample in the UK. Sibling bullying is widespread and found in half of all UK families with adolescents. By contrast, school bullying is experienced by about 1 in 8 adolescents. Sibling bullying showed relationships to a range of individual and family factors. These include age of the adolescents, child sex, number of siblings, whether there were brothers, the frequency that parents engaged in leisure activities with their children, or how often parents quarrelled with them. However, school bullying showed no relationship to these family factors. Young adolescents, those growing up in higher household material deprivation and those involved in sibling bullying as bully/victims or victims, were more likely to be victims in school. Even when allowing for each other, both sibling and school bullying were 
significantly related to higher behaviour problems and unhappiness.

The prevalence of sibling bullying is high, and higher than has been reported in the USA, Israel or Italy (Duncan 1999, Wolke and Samara 2004, Menesini et al 2010). A third of the adolescents both bully their siblings, and are the victims of bullying at the hands of their siblings (bully/victims). These findings are in line with the results of a U.S. study, which found that most children involved in bullying behaviour with their siblings were bully/victims (28.6\%) (Duncan 1999). Two recent reviews on bullying across contexts (Monks et al 2009) and sibling bullying in particular (Wolke and Skew 2012) described that repeated aggression between siblings (bullying), differs from peer bullying in that much more perpetration and victimisation by the same child (bully/victims) is found. In contrast, the prevalence of peer victimisation and the reduction with age found here is remarkably similar to the first such survey of bullying in the UK in 1993 (Whitney and Smith 1993). This is also fairly similar to others studies that investigated both sibling and peer bullying (Wolke and Samara 2004, Duncan 1999). On the other hand, large variation in the prevalence of bullying perpetration is apparent, with between 13.1\% (Wolke and Samara 2004) and 28.4\% (Duncan 1999) who reported to be bullies (pure bullies or bully/victims) in Israel and the USA, but only $1 \%$ admitted to be bullying perpetrators in this study in the UK. Thus very few children admitted to bullying others, a finding replicated in other recent cohorts in the UK (Schreier et al 2009, Sapouna et al 2011). It may indicate that efforts to combat bullying in school (Samara and Smith 2008) have resulted in adolescents being less willing to admit to being perpetrators of bullying in schools in the UK.

Most notable are the different effects that family factors have on bullying at home or at school. Sibling composition has a significant effect on the amount of bullying experienced at home. Those who have brothers as siblings are at increased risk of victimisation, a finding previously reported (Menesini et al 2010). Some suggest that older brother/younger sister dyads are often characterised by higher levels of conflict and less support (Aguilar et al 2001). From an evolutionary perspective, dominance is used to gain access to increased resources and boys or older brothers often use bullying as one way to assert dominance
(Pellegrini and Bartini 2001, Hawley 1999). In contrast, having only sisters or being the youngest sibling, reduces the likelihood of sibling victimisation or perpetration as shown here. Girls often show a caring attitude towards their younger siblings (Brody 2004).

Parent behaviour was also related to sibling bullying. Parents who share little leisure time with their adolescents and who quarrel often with their children, are more likely to have offspring that engage in sibling bullying. No previous study has reported on parenting behaviour in relation to sibling bullying. However, social learning theory (Bandura 1973, Monks et al 2009) suggests that behaviours learned from parents can have both a powerful negative, but also positive, influence on child behaviour. Parents quarrelling with their child may become a model for the relationship of the child with his/her siblings. In contrast, family type, income poverty or household material deprivation was not related to sibling bullying. Thus, the actual quality of the parent -child relationship rather than the economic conditions, relate to the quality of the sibling relationships.

All types of peer victimisation reduced with age. Older adolescents are less likely to become victims of either physical or relational victimisation, a finding reported previously (Whitney and Smith 1993, Smith et al 1999). Contrary to some previous studies, actual parenting behaviour was not found to be related to peer bullying (Baldry and Farrington 2005, Barker et al 2008). Instead, household material deprivation (e.g. the parents not able to afford holidays, keep the house in a good state of repair, replace worn furniture etc.) predicted peer bullying. Adolescence is a period of individuation from the parents, while on the other hand increased affiliation with peers, and adolescents want to fit in with the peer group (Waylen and Wolke 2004). Being unable to afford branded clothes or gadgets that are considered essential may put adolescents at increased risk to be victimised and socially excluded in the peer group. This is not the case within the sibling relationship, as all siblings grow up under the same material conditions. Furthermore, being a victim and in particular a bully/victim at home, was significantly associated with increased likelihood of victimisation in school. This is consistent with all previously carried-out studies of the relationship of sibling and peer bullying (Wolke and Samara 2004, Duncan 
1999, Menesini et al 2010). All sibling relationships involve conflict occasionally, however, when conflicts are severe, repetitive and intentional (bullying), then it appears that these have a profound effect on peer relationships (Brody 2004). Indeed, a recent study found that sibling-directed anti-social behaviour in the family's homes at 3 and 6 years, was predictive of interaction with unfamiliar peers in an experimental setting (Ensor et al 2010). The laboratory situation consisted of three unfamiliar children invited to a triadic play situation. Those young children who showed sustained high anti-social behaviour towards their siblings ( 3 and 6 years) were more likely to bully or refuse to share or interact with unfamiliar peers. Thus experiences with siblings are predictive of bullying unfamiliar peers.

Finally, those who were involved in bullying at home or at school, were found to be at highly increased risk for behaviour problems and were more often unhappy. This replicates results previously reported in an Israeli sample (Wolke and Samara 2004). In particular, those who were bully/victims or bullies at home were at increased risk after controlling for a range of family and demographic variables as well as school bullying. However, school victimisation showed the strongest link to behaviour problems and being unhappy, with five-fold increased odds. This finding replicates recent evidence that school victimisation poses young people at serious risk of mental health problems (Arseneault et al 2010, Reijntjes et al 2010, Sourander et al 2009). This study adds that bullying between siblings increases the risk of becoming a victim of peers at school, and carries an additional independent risk for behaviour problems.

Furthermore, being older, growing up in a reconstituted family as a half sibling or step child, or in family material deprivation with parents who rarely engage in leisure activities with their adolescents, or quarrel with them, further increases the risk of behaviour problems and unhappiness in children. This is consistent with the literature indicating the increasing risk of internalizing and externalising problems with puberty (Waylen and Wolke 2004, Maughan et al 2004) and the adverse effects of step parenting (Dunn 2005), harsh or disengaged parenting, on behaviour and wellbeing
(Belsky et al 2005, Trentacosta et al 2008, Fineknauer et al 2005).

The study has a number of strengths. It is large and representative for households in the UK and utilised interviews with parents on family factors and adolescents' self reports of bullying, behaviour and wellbeing. There are also limitations. The analysis is based on cross-sectional data and does not allow for conclusions regarding causality: Does bullying lead to behaviour problems and less wellbeing, or are children with behaviour problems more often bullied? Both have been reported (Reijntjes et al 2010). Within an observation study, repeated measures of sibling and school bullying, as well as of wellbeing and behaviour problems, are required to determine temporal precedence of bullying while controlling for pre-existing behaviour problems (Schreier et al 2009). This will be possible with future waves (wave 3, wave 5) of Understanding Society. Finally, the youths themselves reported about bullying experience and about their behaviour and happiness, thus potentially inflating relationships. However, previous longitudinal research has shown that whether outcomes are reported by children, mothers or clinical assessors, the results are robust (Schreier et al 2009, Reijntjes et al 2010). However, this needs to be determined in future waves.

Nevertheless, we can conclude that adolescents bullied at home or at school, and particularly victims in both contexts, have more behaviour problems and are much more often unhappy youngsters. Sibling bullying is related to sibling composition, in particular the number of siblings and presence of brothers, as well as less involved or more negative parenting, while school bullying is more dependent on material deprivation at home and negative experiences with siblings. Whether being a victim or bully/victim is a precursor or just a marker of behaviour problems, the current findings add that bullying also takes place at home. Interventions should include training in parenting skills to deal with repeated and serious conflicts between siblings (Wolke and Samara 2004). Strengthening families and parenting skills and increasing social support between siblings are likely to reduce bullying in school and increase wellbeing (Bowes et al 2010). 


\section{Acknowledgements}

Understanding Society, the UK household longitudinal study (UKHLS), is supported by the Economic and Social Research Council (ESRC): Understanding Society: The UK Longitudinal Household Study (RES-586-470001); Understanding Society and the UK Longitudinal Studies Centre (RES-586-47-0002). Prof. Dieter Wolke is Co-Principal Investigator of the UKHLS and preparation of the paper was partly supported by the ESRC.

\section{References}

Aguilar B, O'Brien KM, August GJ, Aoun SL and Hektner JM. (2001) Relationship Quality of Aggressive Children and Their Siblings: A Multiinformant, Multimeasure Investigation. Journal of Abnormal Child Psychology, 29, 479-489.

Analitis F, Velderman MK, Ravens-Sieberer U, Detmar S, Erhart M, Herdman M, Berra S, Alonso J and Rajmil L. (2009) Being Bullied: Associated Factors in Children and Adolescents 8 to 18 Years Old in 11 European Countries. Pediatrics, 123, 569-577.

Arseneault L, Bowes L and Shakoor S. (2009) Bullying victimization in youths and mental health problems: "Much ado about nothing"? Psychological Medicine, First View, 1-13.

Arseneault L, Cannon M, Fisher, HL, Polanczyk G, Moffitt TE and Caspi A. (2011) Childhood Trauma and Children's Emerging Psychotic Symptoms: A Genetically Sensitive Longitudinal Cohort Study. American Journal of Psychiatry, 168, 65-72.

Azmitia $\mathrm{M}$ and Hesser J. (1993) Why siblings are important agents of cognitive development: a comparison of siblings and peers. Child Development, 64, 430-444.

Baldry A and Farrington DP. (2005) Protective factors as moderators of risk factors in adolescence bullying. Social Psychology of Education 8, 263-284.

Baldry AC and Farrington DP. (1998) Parenting influences on bullying and victimisation. Legal and Criminological Psychology, 3, 237-254.

Ball HA, Arseneault L, Taylor A, Maughan B, Caspi A and Moffitt TE. (2008) Genetic and environmental influences on victims, bullies and bully-victims in childhood. Journal of Child Psychology and Psychiatry, 49, 104-112.

Bandura A. (1973) Aggression: A social learning analysis. Prentice-Hall, Englewood Cliffs, N.J.

Barker ED, Boivin M, Brendgen M, Fontaine N, Arseneault L, Vitaro F, Bissonnette C and Tremblay RE. (2008) Predictive Validity and Early Predictors of Peer-Victimization Trajectories in Preschool. Archives of General Psychiatry, 65, 1185-1192.

Bebbington PE, Bhugra D, Brugha T, Singleton N, Farrell M, Jenkins R, Lewis G and Meltzer H. (2004) Psychosis, victimisation and childhood disadvantage: evidence from the second British National Survey of Psychiatric Morbidity. British Journal of Psychiatry, 185, 220-6.

Belsky J, Jaffee SR, Sligo J, Woodward L and Silva PA. (2005) Intergenerational transmission of warmsensitive-stimulating parenting: A prospective study of mothers and fathers of 3-year-olds. Child Development, 76, 384-396.

Berdondini L and Smith PK. (1996) Cohesion andpower in the families of children involved in bully victim problems at school: An Italian replication. Journal of Family Therapy, 18, 99-102.

Bowers L, Smith PK and Binney V. (1992) Cohesion and power in the families of children involved in bully/victim problems at school. Journal of Family Therapy, 14, 371-387.

Bowers L, Smith PK and Binney V. ( 1994) Perceived family relationships of bullies, victims and bully-victims in middle childhood. Journal of Social and Personal Relationships, 11, 215-232.

Bowes L, Maughan B, Caspi A, Moffitt TE and Arseneault L. (2010) Families promote emotional and behavioural resilience to bullying: evidence of an environmental effect. Journal of Child Psychology and Psychiatry, 51, 809-817.

Bowes LMS, Arseneault LPD, Maughan BPD, Taylor APD, Caspi APD and Moffitt TEPD. (2009) School, Neighborhood, and Family Factors Are Associated With Children's Bullying Involvement: A Nationally Representative Longitudinal Study. Journal of the American Academy of Child \& Adolescent Psychiatry, 48, 545-553.

Brody GH. (2004) Siblings' Direct and Indirect Contributions to Child Development. Current Directions in Psychological Science, 13, 124-126.

Bronfenbrenner U. (1977) Toward an experimental ecology of human development. American Psychologist, 32, 513-531.

Bronfenbrenner U. (1979) The ecology of human development: Experiments by nature and design, Harvard University Press, Cambridge, MA.

Cicirelli VG. (1995) Sibling relationships across the lifespan, Plenum Press, New York.

Dishion TJ, French DC and Patterson G. (1995) The development and ecology of antisocial behavior. In: D. Cicchetti and DJ Cohen. eds. Developmental psychopathology, Vol.2: Risk, disorder, and adaptation. John Wiley \& Sons, New York. 
Due P, Merlo J, Harel-Fisch Y, Damsgaard MT, Soc MS, Holstein BE, Soc MS, Hetland J, Currie C, Gabhainn SN, De Matos MG and Lynch J. (2009) Socioeconomic Inequality in Exposure to Bullying During Adolescence: A Comparative, Cross-Sectional, Multilevel Study in 35 Countries. American Journal of Public Health, 99, 907-914.

Duncan RD. (1999) Peer and sibling aggression: an investigation of intra- and extra-familial bullying. Journal of Interpersonal Violence, 14, 871-886.

Dunn J. (2005) Daddy doesn't live here anymore.The Psychologist, 18, 28-31.

Ensor R, Marks A, Jacobs L and Hughes C. (2010) Trajectories of antisocial behaviour towards siblings predict antisocial behaviour towards peers. Journal of Child Psychology and Psychiatry, 51, 1208-1216.

Fergusson D, Swain-Campbell N and Horwood J. (2004) How does childhood economic disadvantage lead to crime? Journal of Child Psychology and Psychiatry, 45, 956-966.

Fineknauer C, Engels RCME and Baumeister RF. (2005) Parenting behaviour and adolescent behavioural and emotional problems: The role of self-control. International Journal of Behavioral Development, 29, 58-69.

Gass K, Jenkins J and Dunn J. (2007) Are sibling relationships protective? A longitudinal study. Journal of Child Psychology and Psychiatry, 48, 167-175.

Georgiou S. (2008) Parental style and child bullying and victimization experiences at school. Social Psychology of Education, 11, 213-227.

Goodman R. (2001). Psychometric properties of the strengths and difficulties questionnaire. Journal of the American Academy of Child Adolescent Psychiatry, 40, 1337-45.

Hamburger ME, Basile KC and Vivola AM. (2011) Measuring bullying victimization, perpetration, and bystander experiences: A compendium of assessment tools. Center for Disease Control and Prevention, National Center for Injury Prevention and Control, Atlanta, GA. http://www.cdc.gov/violenceprevention/

Hart CH, Nelson DA, Robinson CC, Olsen SF, Mcneilly-Choque MK, Porter CL and McKee TR. (2000) Russian parenting styles and family processes: Linkages with subtypes of victimisation and aggression. In: KA Kerns, JM Contreras and AM Neal-Barnett. eds. Family and peers: Linking two social worlds. Praeger, Westport, CT.

Hawker DJS and Boulton MJ. (2000) Twenty years' research on peer victimization and psychosocial adjustment: a meta-analytic review of cross-sectional studies. Journal of Child Psychology and Psychiatry, 41, 441-456.

Hawley PH. (1999) The Ontogenesis of Social Dominance: A Strategy-Based Evolutionary Perspective. Developmental Review, 19, 97-132.

Haynie DL, Nansel T, Eitel P, Crump AD, Saylor K, Yu K and Simons-Morton B. (2001) Bullies, victims, and bully/victims: Distinct groups of at-risk youth. Journal of Early Adolescence, 21, 29-49.

Ingoldsby EM, Shaw DS and Garcia MM. (2001) Intrafamily conflict in relation to boys' adjustment at school. Development and Psychopathology, 13, 35-52.

Jenkins J, Simpson A, Dunn J, Rasbash J and O'Connor TG. (2005) Mutual influence of marital conflict and children's behavior problems: Shared and nonshared family risks. Child Development, 76, 24-39.

Knies G. (2011) Life satisfaction and material well-being of young people in the UK. In S McFall. ed. Understanding Society: Early findings from the first wave of the UK's household longitudinal study. Economic and Social Research Council, London.

Kumpulainen K, Rasanen E and Puura K. (2001) Psychiatric Disorders and the Use of Mental Health Among Children Involvedin Bullying. Aggressive Behavior, 27, 102-110.

Ladd GW and Kochenderfer-Ladd B. (1998) Parenting Behaviors and Parent-Child Relationships: Correlates of Peer Victimisation in Kindergarten? Developmental Psychology, 34, 1450-1458.

Maughan B, Rowe R, Messer J, Goodman R and Meltzer H. (2004) Conduct Disorder and Oppositional Defiant Disorder in a national sample: developmental epidemiology. Journal of Child Psychology and Psychiatry, 45, 609-621.

Menesini E, Camodeca M and Nocentini A. (2010) Bullying among siblings: The role of personality and relational variables. British Journal of Developmental Psychology, 28, 921-939.

Monks CP, Smith PK, Naylor P, Barter C, Ireland JL and Coyne I. (2009) Bullying in different contexts: Commonalities, differences and the role of theory. Aggression and Violent Behavior, 14, 146-156.

Nansel TR, Craig W, Overpeck MD, Saluja G, Ruan WJ and Health Behaviour In School-Aged Children Bullying Analyses Working Group. (2004) Cross-national Consistency in the Relationship Between Bullying Behaviors and Psychosocial Adjustment. Archives of Pediatrics and Adolescent Medicine, 158, 730 736.

Olweus D. (1993) Bullying in schools: what we know and what we can do. Blackwell Publishers, Oxford.

Olweus D. (1994) Annotation: Bullying at school: Basic factsand effects of a school based intervention program. Journal of Child Psychology and Psychiatry, 35, 1171-1190.

Pellegrini AD and Bartini M. (2001) Dominance in early adolescent boys: Affiliative and aggressive dimensions and possible functions. Merrill-Palmer Quarterly, 47, 142-163. 
Perren S and Hournung R. (2005) Bulling and delinquency in adolescence: Victim's and perpetrators' family and peer relations. Swiss Journal of Psychology 64, 51-64.

Reijntjes A, Kamphuis JH, Prinzie P and Telch MJ. (2010) Peer victimization and internalizing problems in children: A meta-analysis of longitudinal studies. Child Abuse \& Neglect, 34, 244-252.

Samara M and Smith PK. (2008) How schools tackle bullying, and the use of whole school policies: changes over the last decade. Educational Psychology, 28, 663-676.

Sapouna M, Wolke D, Vannini N, Watson S, Woods S, Schneider W, Enz S and Aylett R. (2011) Individual and social network predictors of the short-term stability of bullying vicitimization in the United Kingdom and Germany. British Journal of Educational Psychology. (doi: 10.1111/j.2044-8279.2011.02022.x).

Schafer M, Korn S, Brodbeck FC, Wolke D and Schulz H. (2005) Bullying roles in changing contexts: The stability of victim and bully roles from primary to secondary school. International Journal of Behavioral Development, 29, 323-335.

Schreier A, Wolke D, Thomas K, Horwood J, Hollis C, Gunnell D, Lewis G, Thompson A, Zammit S, Duffy L, Salvi G and Harrison G. (2009) Prospective Study of Peer Victimization in Childhood and Psychotic Symptoms in a Nonclinical Population at Age 12 Years. Archives of General Psychiatry, 66, 527-536.

Shields A and Cicchetti D. (2001) Parental maltreatment and emotion dysregulation as risk factors for bullying and victimization in middle childhood. Journal of Clinical Child Psychology 30, 349-363.

Smith PK. (2004) Bullying: recent developments. Child and Adolescent Mental Health, 9, 98-103.

Smith PK, Morita Y, Junger-Tas J, Olweus D, Catalano R and Slee P. (1999) The nature of school bullying: A cross-national perspective, London, Routledge.

Smith PK and Myron-Wilson R. (1998) Parenting and school bullying. Clinical Child Psychology and Psychiatry, 3, 405-417.

Sourander A, Jensen P, Ronning JA, Niemela S, Helenius H, Sillanmaki L, Kumpulainen K, Piha J, Tamminen T, Moilanen I and Almqvist F. (2007) What Is the Early Adulthood Outcome of Boys Who Bully or Are Bullied in Childhood? The Finnish "From a Boy to a Man" Study. Pediatrics, 120, 397-404.

Sourander A, Ronning J, Brunstein-Klomek A, Gyllenberg D, Kumpulainen K, Niemela S, Helenius H, Sillanmaki L, Ristkari T, Tamminen T, Moilanen I, Piha J and Almqvist F. (2009) Childhood Bullying Behavior and Later Psychiatric Hospital and Psychopharmacologic Treatment: Findings From the Finnish 1981 Birth Cohort Study. Archives of General Psychiatry, 66, 1005-1012.

Sroufe LA, Coffino B and Carlson EA. (2010) Conceptualizing the role of early experience: Lessons from the Minnesota longitudinal study. Developmental Review, 30, 36-51.

Stassen Berger K. (2007) Update on bullying at school: Science forgotten? Developmental Review, 27, 90126.

Stormshak EA, Bellanti CJ and Bierman KL. (1996) The quality of sibling relationships and the development of social competence and behavioral control in aggressvie children. Developmental Psychology, 32, 7989.

Sugden K, Arseneault L, Harrington H, Moffitt TE, Williams B and Caspi A. (2010) Serotonin Transporter Gene Moderates the Development of Emotional Problems Among Children Following Bullying Victimization. Journal of the American Academy of Child \& Adolescent Psychiatry, 49, 830-840.

Swearer SM and Doll B. (2001) Bullying in schools. Journal of Emotional Abuse, 2, 7-23.

Trentacosta CJ, Hyde LW, Shaw DS, Dishion TJ, Gardner F and Wilson M. (2008) The relations among cumulative risk, parenting, and behavior problems during early childhood. Journal of Child Psychology and Psychiatry, 49, 1211-1219.

Veenstra R, Lindenberg S, Oldehinkel AJ, De Winter AF, Verhulst FC, and Ormel J. (2005) Bullying and victimization in elementary schools: A comparison of bullies, victims, Bully/Victims, and uninvolved preadolescents. Developmental Psychology, 41, 672-682.

Waylen A and Wolke D. (2004) Sex ' $n$ ' drugs ' $n$ ' Rock ' $n$ ' Roll: the Meaning and Social Consequences of Pubertal Timing. European Journal of Endocrinology, 151, 1-10.

Whitney I and Smith PK. (1993) A survey of the nature and extent of bullyingin junior/middle and secondary schools. Educational Research, 35, 3-25.

Williams C, Horwood J, Northstone K, Herrick D, Waylen A, Wolke D and Grp AS. (2006) The timing of patching treatment and a child's wellbeing. British Journal of Ophthalmology, 90, 670-671.

Wolke D and Samara MM. (2004) Bullied by siblings: association with peer victimisation and behaviour problems in Israeli lower secondary school children. Journal of Child Psychology and Psychiatry, 45, 1015-1029.

Wolke D and Skew AJ. (2011) Bullied at home and at school: Relationship to behaviour problems and unhappiness. In S McFall. ed. Understanding Society: Early findings from the first wave of the UK's household longitudinal study. Economic and Social Research Council, London.

Wolke D and Skew AJ. (2012) Bullying among siblings. International Journal of Adolescent Medicine and Health, 24,( forthcoming)

Wolke D, Woods S, Bloomfield L and Karstadt L. (2000) The association between direct and relational bullying and behaviour problems among primary school children. Journal of Child Psychology and Psychiatry, 41, 989-1002. 
Wolke D, Woods S and Samara M. (2009) Who escapes or remains a victim of bullying in primary school? British Journal of Developmental Psychology, 27, 835-851.

Wolke D, Woods S, Schulz H and Stanford K. (2001) Bullying and victimisation of primary school children in South England and South Germany: Prevalence and school factors. British Journal of Psychology, 92, 673-696.

Woods S and Wolke D. (2004) Direct and relational bullying among primary school children and academic achievement. Journal of School Psychology, 42, 135-155.

\section{Endnote}

${ }^{i}$ For the analyses of bullying with behaviour problems and happiness, the samples were further reduced due to item non-response on these two variables, resulting in sample sizes of 1,670 and 1,734 , respectively. 